\title{
Seleksi Awal Calon Pejantan Sapi Aceh Berdasarkan Berat Badan
}

\author{
Early Selection for Aceh Candidate Bull Based on Body Weight
}

\author{
Widya Pintaka Bayu Putra ${ }^{1}$, Sumadi $^{2}$, Tety Hartatik ${ }^{2}$, dan Hendra Saumar ${ }^{3}$ \\ ${ }^{1}$ Lembaga Ilmu Pengetahuan Indonesia \\ Jln. Raya Bogor Km. 46 Cibinong, Bogor, Jawa barat 16911 \\ ${ }^{2}$ Laboratorium Pemuliaan Ternak, Fakultas Peternakan, Universitas Gadjah Mada \\ Jln. Fauna No. 5 Bulaksumur, Sleman, Yogyakarta 55281 \\ ${ }^{3}$ Balai Pembibitan Ternak Unggul - Hijauan Pakan Ternak (BPTU-HPT) Sapi Aceh Indrapuri \\ Jln. Raya Medan - Banda Aceh Km. 25 Indrapuri, Aceh Besar, Aceh 23363
}

\begin{abstract}
The objective of the study was to determine the selection for Aceh candidate bull at Indrapuri's Breeding and Forages Centre (IBFC) of Aceh Cattle based on body weight. The evaluation in the candidate bulls selection were birth weight $(\mathrm{BW})$, weaning weight (WW), yearling weight (YW) and adult weight (AW). The number of bulls that were evaluation in 2014 was 34 bulls. Based on production test, the best ten candidate bulls were found with adult weight ratio (AWR) 1.03 to 1.65. All bulls were recommended as candidate bulls for next progeny test program.
\end{abstract}

Key words: Aceh cattle, production traits, body weight, adult weight ratio.

\begin{abstract}
ABSTRAK
Penelitian ini bertujuan untuk memilih calon pejantan sapi Aceh yang dipelihara di Balai Pembibitan Ternak Unggul - Hijauan Pakan Ternak (BPTU-HPT) Sapi Aceh Indrapuri berdasarkan berat badan ternak. Evaluasi yang dilakukan pada seleksi calon pejantan meliputi catatan berat lahir (BL), berat sapih (BS), berat setahunan (BY) dan berat dewasa (BD). Jumlah ternak yang digunakan untuk dievaluasi pada tahun 2014 adalah 34 ekor. Berdasarkan data catatan produksi diperoleh 10 calon pejantan sapi Aceh terbaik dengan kisaran nilai rasio berat dewasa (RBD) 1,03 sampai 1,65. Kesepuluh sapi Aceh ini akan direkomendasikan sebagai calon pejantan untuk progam uji zuriat pada tahap seleksi berikutnya.
\end{abstract}

Kata kunci: sapi Aceh, catatan produksi, berat badan, rasio berat dewasa.

\section{PENDAHULUAN}

Sapi Aceh merupakan salah satu plasma nutfah nasional yang perlu dipertahankan kelestariannya (Jamaliah, 2010). Sapi Aceh memiliki keunggulan karakteristik seperti fertilitas tinggi, lebih tahan terhadap kondisi lingkungan yang kurang baik, cepat beradaptasi apabila dihadapkan dengan lingkungan yang baru dan cepat berkembang biak (Umartha,
2005). Sapi Aceh memegang peranan penting sebagai sumber daging dalam negeri. Tingginya permintaan sapi Aceh belum diimbangi dengan usaha-usaha pembibitan atau hal-hal yang berkaitan dengan perbaikan mutu genetik ternak. Dampak dari eksploitasi ternak seperti di atas akan berakibat pada penurunan mutu genetik ternak. Disamping itu, penurunan kualitas genetik juga akibat adanya seleksi negatif (Hardjosubroto, 1994). Sapi Aceh 
memiliki masalah utama dalam upaya pengembangannya yaitu rendahnya kualitas bibit yang diduga akibat dari peristiwa silang dalam (inbreeding) dan manajemen pemeliharaan ternak yang tidak baik. Warwick et al. (1990) menyatakan bahwa perkawinan silang dalam pada sapi potong mengakibatkan penurunan berat badan sebesar 2,5-5,0 kg setiap kenaikan $10 \%$ silang dalam. Oleh karena itu diperlukan usaha-usaha nyata perbaikan mutu genetik dan produktivitas ternak. Salah satunya adalah dengan seleksi pejantan berdasarkan catatan produksi ternak.

Seleksi ternak berdasarkan catatan produksi ternak merupakan salah satu metode seleksi pada ternak untuk mengetahui performans atau penampilan pada beberapa ternak terpilih mulai dari lahir sampai dengan dewasa. Performans ternak yang baik akan diwariskan kepada anaknya, sehingga seleksi berdasarkan performans ternak menjadi sangat penting (Hardjosubroto, 1994). Beberapa performans ternak yang harus dicatat di BPTU-HPT Sapi Aceh Indrapuri adalah berat lahir (BL), berat sapih (BS), berat setahunan (BY) berat dewasa (BD). Dengan mengetahui catatan produksi ternak maka akan diperoleh gambaran calon pejantan yang memiliki produktivitas tinggi dan berkualitas.

Seleksi pada calon pejantan sapi Aceh di BPTU-HPT Sapi Aceh Indrapuri menggunakan catatan produksi dengan alasan lebih cepat dan efisien disamping juga pertimbangan biaya. Pedet yang baru lahir secara langsung sudah mulai dievaluasi pertumbuhannya untuk dipilih sebagai calon pejantan pada saat pedet dewasa. Ternak yang memiliki catatan produksi yang baik direkomendasikan untuk mengikuti tahap seleksi berikutnya, yaitu uji keturunan (progeny test). Selain sifat kuantitatif (BL, BS, BY dan BD) seleksi pada sapi Aceh juga dilakukan berdasarkan sifat kualitatifnya antara lain warna rambut, bentuk rangka, bentuk kepala, bentuk kaki, bentuk kuku/teracak, bentuk scrotum dan kelainan yang lain seperti warna rambut putih atau hitam dan warna dahi putih. Menurut Keputusan Menteri Pertanian RI Nomor: 2907/Kpts/OT.140/6/2011, standar mutu bibit sapi Aceh memiliki ciri-ciri warna rambut merah bata, warna hitam pada moncong hidung, teracak, rambut ekor dan tanduk dan terdapat garis belut pada punggung (Jamaliah, 2010).

Melihat kenyataan tersebut, dalam upaya pengembangan sapi Aceh di suatu wilayah tertentu perlu dilengkapi dengan rancangan peningkatan mutu genetik ternak (Hardjosubroto, 1994). Seleksi berdasarkan catatan produksi ternak sangat diperlukan untuk mempersiapkan dan mengintroduksi ternak unggul pada daerah-daerah potensial sumber bibit dengan menyiapkan pejantan unggul.

\section{MATERI DAN METODE}

Sejumlah 34 ekor calon pejantan sapi Aceh umur \pm 3 tahun dievaluasi catatan produksinya yang meliputi berat lahir (BL), berat sapih (BS), berat setahunan (BY) dan berat dewasa (BD) 
untuk dipilih sebagai 10 calon pejantan sapi Aceh terbaik untuk program uji keturunan. Metode yang digunakan untuk melakukan seleksi calon pejantan sapi Aceh adalah berdasarkan rasio berat badan (RBB) yang dihitung menurut Hardjosubroto (1994) sebagai berikut:

$$
\mathrm{RBB}=\frac{\text { Berat badan individu }}{\text { Berat badan populasi }}
$$

Keterangan:

$\mathrm{RBB}=$ rasio berat badan

Berat badan harus dikoreksi terlebih dahulu sesuai petunjuk Hardjosubroto (1994):

$$
\begin{aligned}
& \mathrm{BS}_{\mathrm{T}}=\left(\frac{\mathrm{BS}-\mathrm{BL}}{\text { umur }} \times 205+\mathrm{BL}\right) \times(\mathrm{FKUI}) \\
& \mathrm{BY}_{\mathrm{T}}=\frac{\mathrm{BY}-\mathrm{BS}}{\text { tenggang waktu }} \times 160+\mathrm{BS}_{\mathrm{T}} \\
& \mathrm{BA}_{\mathrm{T}}=\frac{\mathrm{BA}-\mathrm{BS}}{\text { tenggang waktu }} \times 345+\mathrm{BS}_{\mathrm{T}}
\end{aligned}
$$

Keterangan:

$$
\begin{aligned}
& \mathrm{BS}=\text { berat sapih } \\
& \mathrm{BY}=\text { berat yearling atau setahunan } \\
& \mathrm{BA}=\text { berat akhir } \\
& \mathrm{BL}_{\mathrm{T}}=\text { berat lahir terkoreksi } \\
& \mathrm{BS}_{\mathrm{T}}=\text { berat sapih terkoreksi ke umur } \\
& 205 \text { hari } \\
& \mathrm{BY}_{\mathrm{T}}=\text { berat yearling atau setahunan } \\
& \text { terkoreksi ke umur } 365 \text { hari }
\end{aligned}
$$

$\mathrm{BA}_{\mathrm{T}}=$ berat akhir terkoreksi ke umur 550 hari.

FKUI $=$ faktor koreksi umur induk

Faktor koreksi umur induk mengikuti petunjuk Hardjosubroto (1994) dihitung dengan faktor perkalian sebagai berikut: umur induk 2 tahun $(1,15) ; 3$ tahun $(1,10)$; 4 tahun $(1,05) ; 5$ sampai 10 tahun $(1,00)$ dan 11 tahun keatas $(1,05)$.

Semua data dianalisis secara deskriptif dan dibandingkan dengan Standard Nasional Indonesia (SNI).

\section{HASIL DAN PEMBAHASAN}

\section{Berat badan sapi Aceh}

Hasil penimbangan dari 34 sapi jantan yang dievaluasi catatan produksinya pada tahun 2014 ditampilkan pada Tabel 1. Berat dewasa sapi Aceh pada penelitian ini menunjukkan hasil yang lebih rendah dari Standar Nasional Indonesia (SNI) bibit sapi Aceh yang ditetapkan pemerintah pada tahun 2011. Menurut Jamaliah (2012) standar SNI berat dewasa sapi Aceh adalah $253,00 \pm 65,00 \mathrm{~kg}$. Apabila ukuran statistik vital dalam penelitian ini dibandingkan dengan SNI maka sapi Aceh dewasa pada penelitian ini memiliki ukuran statistik yang lebih rendah

Tabel 1. Perkembangan berat badan calon pejantan Sapi Aceh beradasarkan catatan produksi ternak

\begin{tabular}{lllccc}
\hline Sifat kuantitatif $(\mathrm{kg})$ & $\mathrm{N}$ & Nilai terendah & Nilai tertinggi & KV $(\%)$ & Rataan \pm SD \\
\hline Berat lahir & 34 & 12,00 & 14,00 & 9,15 & $13,11 \pm 1,20$ \\
Berat sapih & 34 & 28,96 & 69,30 & 21,78 & $47,19 \pm 10,28$ \\
Berat setahunan & 34 & 41,80 & 113,23 & 23,94 & $72,75 \pm 17,42$ \\
Berat dewasa & 34 & 56,66 & 167,48 & 24,63 & $101,24 \pm 24,93$ \\
\hline
\end{tabular}

$\mathrm{N}$ : total observasi dan KV: koefisien variasi 
Data bobot badan dan dimensi ukuran tubuh sapi Aceh pada penelitian ini juga menunjukkan hasil yang lebih rendah dibandingkan dengan hasil penelitian Abdullah et al. (2006) yaitu BY jantan $123,34 \pm 25,38 \mathrm{~kg}$ dan pada $\mathrm{BD}$ jantan $153,17 \pm 25,58 \mathrm{~kg}$. Rata-rata BL sapi Aceh pada penelitian juga lebih rendah dari hasil penelitian Umartha (2005) yaitu pada jantan $15,90 \mathrm{~kg}$. Perbedaan hasil penelitian ini dengan beberapa hasil penelitian sebelumnya disebabkan karena sapi Aceh di lokasi penelitian sedang dalam proses seleksi. Sapi Aceh di pusat pembibitan ini diperoleh dari kelompok-kelompok ternak milik masyarakat yang dipelihara secara tradisional. Dengan berjalannya proses seleksi ini akan muncul bibit-bibit unggul yang dapat meningkatkan performans ternak. Penggunaan pejantan dan induk yang baik serta penyingkiran ternak (culling) pada sifat-sifat yang jelek dapat memperbaiki mutu genetik ternak (Lasley
1978). Rendahnya berat badan pada penelitian dibandingkan dengan SNI dan Abdullah et al. (2006) dapat disebabkan karena sapi Aceh pada penelitian ini berasal dari peternakan rakyat tradisional, sehingga performans sapi tersebut dibawah SNI. Diharapkan proses seleksi pada sapi Aceh di BPTU-HPT Sapi Aceh Indrapuri dapat berjalan dengan baik sehingga mampu memproduksi bibit sapi Aceh yang memenuhi SNI.

\section{Rasio Berat Badan}

Hasil penilaian ternak berdasarkan rasio berat badan (RBB) tersaji pada Tabel 2. Sapi yang memiliki nilai RBB tertinggi merupakan ternak yang memiliki performans yang baik. Nilai RBB tertinggi pada BS, BY dan BD dicapai pada sapi nomor A100412, sedangakan sapi nomor A100317 memiliki nilai RBB pada BL tertinggi.

Tabel 2. Hasil penilaian ternak berdasarkan rasio berat badan pada calon pejantan sapi Aceh terbaik di BPTU-HPT Sapi Aceh Indrapuri

\begin{tabular}{|c|c|c|c|c|c|c|c|c|c|c|c|}
\hline \multirow{2}{*}{ Rank } & \multicolumn{3}{|c|}{ Kode } & \multicolumn{4}{|c|}{ Berat badan $(\mathrm{kg})$} & \multicolumn{4}{|c|}{ RBB } \\
\hline & Calf & Bull & Cow & $\mathrm{BL}$ & BS & $\mathrm{BY}$ & $\mathrm{BD}$ & $\mathrm{BL}$ & BS & $\mathrm{BY}$ & $\mathrm{BD}$ \\
\hline 1 & A100412 & P0752 & P0745 & 13,00 & 69,30 & 113,23 & 167,48 & 0,99 & 1,47 & 1,56 & 1,65 \\
\hline 2 & A100520 & P0751 & A170 & 13,00 & 67,35 & 109,77 & 152,95 & 1,01 & 1,43 & 1,51 & 1,51 \\
\hline 3 & A100317 & P0752 & A0643 & 15,00 & 61,87 & 98,45 & 135,25 & 1,14 & 1,31 & 1,35 & 1,34 \\
\hline 4 & A100517 & A001 & A90 & 12,00 & 56,32 & 90,92 & 136,09 & 0,93 & 1,19 & 1,25 & 1,34 \\
\hline 5 & A 100503 & $\mathrm{P} 0751$ & A671 & 12,60 & 51,38 & 82,12 & 129,72 & 1,01 & 1,09 & 1,13 & 1,28 \\
\hline 6 & A100314 & P0752 & A0639 & 14,00 & 56,94 & 90,45 & 121,18 & 1,07 & 1,21 & 1,24 & 1,20 \\
\hline 7 & AP100515 & A004 & 1288 & 12,00 & 60,64 & 98,61 & 118,52 & 0,92 & 1,28 & 1,36 & 1,17 \\
\hline 8 & A100514 & P0751 & A0591 & 13,00 & 55,76 & 89,13 & 111,76 & 0,93 & 1,18 & 1,23 & 1,10 \\
\hline 9 & A100421 & A001 & P0702 & 13,00 & 54,32 & 86,57 & 105,91 & 0,93 & 1,15 & 1,19 & 1,05 \\
\hline 10 & A100811 & P0752 & A74 & 13,00 & 60,12 & 81,85 & 104,36 & 0,99 & 1,27 & 1,13 & 1,03 \\
\hline
\end{tabular}

BL: berat lahir, BS: berat sapih, BY: berat setahunan, BD: berat dewasa. RBB: rasio berat badan

Seleksi ternak berdasarkan BL saat ini jarang dilakukan karena akan meningkatkan kejadian dystochia (susah beranak) pada induk (Falconer dan Mackay, 1996). Oleh karena itu apabila akan menggunakan BL harus diikuti 
dengan melakukan seleksi induk berdasarkan tinggi pinggul dan lebar pinggul (Hardjosubroto, 1994). Yusran et al. (1995) melaporkan bahwa tidak terdapat perbedaan yang signifikan pada rata-rata $\mathrm{BL}$ pada keturunan dari tiga ekor calon pejantan sapi Madura selama uji zuriat di Sub Balai Penelitian Ternak, Grati, Pasuruan, Provinsi Jawa Timur dari tahun 1990 sampai 1995.

Berdasarkan Tabel 2 diketahui bahwa dari 10 calon pejantan sapi Aceh terbaik, sebanyak empat ekor (40\%) berasal dari pejantan P0752, tiga ekor $(30 \%)$ berasal dari pejantan P0751, dua ekor (20\%) berasal dari pejantan A001 dan satu ekor (10\%) berasal dari pejantan A004. Dengan demikian dapat disimpulkan bahwa pejantan P0751 dan P0752 mempunyai mutu genetik yang unggul walaupun harus dibuktikan dengan menghitung nilai pemuliaan pejantannya (Hardjosubroto, 1994).

Pada Gambar 1 terlihat bahwa sapi yang memiliki nilai rasio berat dewasa (RBD) diatas 1,40 merupakan sapi yang memiliki performans diatas rata-rata populasi dan dicapai oleh sapi A100412 dan A100520. Dengan demikian pelaksanaan uji keturunan (uji zuriat) pada calon pejantan sapi Aceh dapat menggunakan dua ekor sapi saja sehingga akan menghemat biaya. Hardjosubroto (1993) menjelaskan bahwa selain berguna untuk memilih pejantan terbaik, uji zuriat juga berguna untuk meningkatkan mutu genetik ternak hasil keturunannya.

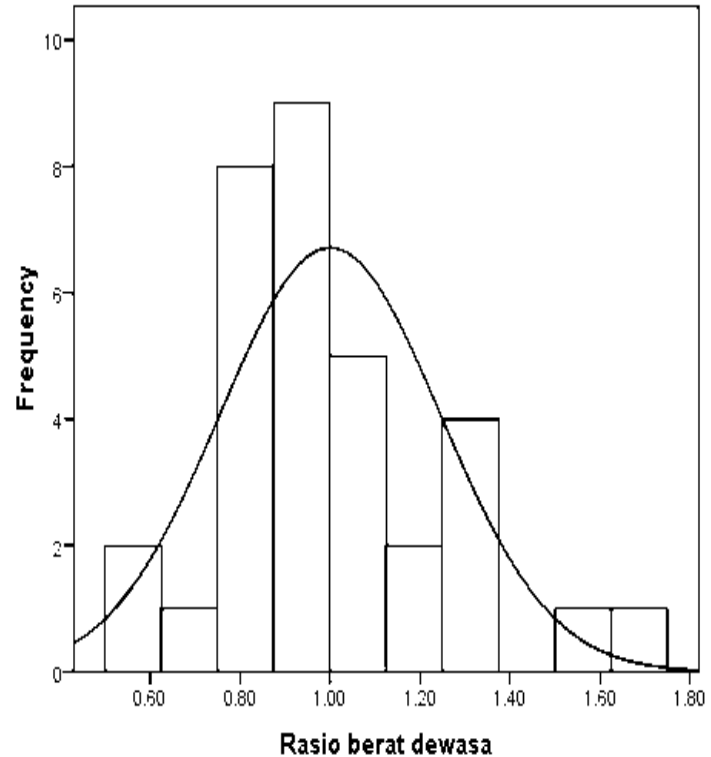

Gambar 1. Histogram dan kurva normal pada rasio berat dewasa calon pejantan sapi Aceh di BPTUHPT Sapi Aceh

Ukuran tubuh pada penelitian ini tidak dianalisis karena variasi ukuran tubuh pada sapi Aceh di BPTU-HPT Sapi Aceh relatif kecil. Berdasarkan Tabel 1 terlihat bahwa koefisien variasi $(\mathrm{KV})$ pada masing-masing berat badan termasuk kategori besar ( $\mathrm{KV}>20 \%)$ sehingga akan memberikan peringkat yang berbeda pada masing-masing pejantan. Hasil uji performans pada sapi Bali di BPTU Sapi Bali pada tahun 2013 berdasarkan ukuran tubuh menunjukkan terdapat perbedaan peringkat pejantan sapi Bali yang diukur berdasarkan ukuran tubuh antara lain lingkar dada dan tinggi gumba (Patmawati et al., 2013). Oleh karena berat badan dapat digunakan sebagai salah satu kriteria seleksi ternak, khususnya untuk uji performans. 


\section{KESIMPULAN}

Seleksi untuk memilih calon pejantan sapi Aceh dapat dilakukan berdasarkan catatan produksi ternak antara lain berat lahir, berat sapih, berat setahunan dan berat dewasa. Perhitungan rasio berat badan dapat menjadi metode alternatif untuk seleksi ternak apabila estimasi parameter genetik pada ternak tersebut belum dilakukan.

\section{UCAPAN TERIMAKASIH}

Penulis mengucapkan terimakasih kepada seluruh staf dan karyawan di BPTU-HPT Sapi Aceh Indrapuri yang telah membantu jalannya penelitian dari awal hingga selesainya penelitian ini.

\section{DAFTAR PUSTAKA}

Abdullah, M.A.N., R.R. Noor, H. Martojo, D.D. Solihin dan E. Hendirawan. 2006. Keragaman fenotipik sapi Aceh di Nanggroe Aceh Darussalam. Jurnal Pengembangan Ternak Tropis. 32: 11-21.

Falconer, D.S. and Mackay, T.F. 1996. Introduction to Quantitative Genetics. $4^{\text {th }}$ Ed. Department of Genetics. North Canada State University, Prince George.

Hardjosubroto, W. 1993. Analisis progeny test untuk menghitung nilai pemuliaan pejantan. Buletin

Peternakan. 17: 1-10.

Jamaliah. 2010. Pelestarian Plasma Nutfah Sapi Aceh. Balai Pembibitan Ternak Unggul (BPTU) sapi

Aceh Indrapuri. Aceh

Jamaliah. 2012. Pedet Sapi Aceh dan Penanganannya Pada Balai Pembibitan Ternak Unggul (BPTU) Indrapuri, Aceh.

Lasley JF. 1978. Genetic of livestock improvement. New Jersey (USA): Prentice Hall. Inc.

Patmawati, N.W., N.N. Trinayani, M. Siswanto, I.N. Wandita dan I.K. Puja. 2013. Seleksi awal pejantan sapi Bali berdasarkan catatan produksi. Jurnal Ilmu dan Kesehatan Hewan. 1(1): $\quad$ 2933.

Umartha, B.A. 2005. Mengenal Karakteristik Sapi Aceh. Balai Pembibitan Ternak Unggul (BPTU) Sapi Aceh Indrapuri, Banda Aceh.

Warwick, E.J., J.W. Astuti dan W. Hardjosubroto. 1990. Pemuliaan Ternak. Gadjah Mada University Press, Yogyakarta.

Yusran, M.A., K. Ma'sum, D.B. Wiyono. 1995. Evaluasi Nilai Pemuliaan Calon Pejantan Donor Semen Beku Sapi Madura Melalui Uji Keturunan. Jurnal Ilmiah Penelitian Ternak Grati. 4(1): 1723 